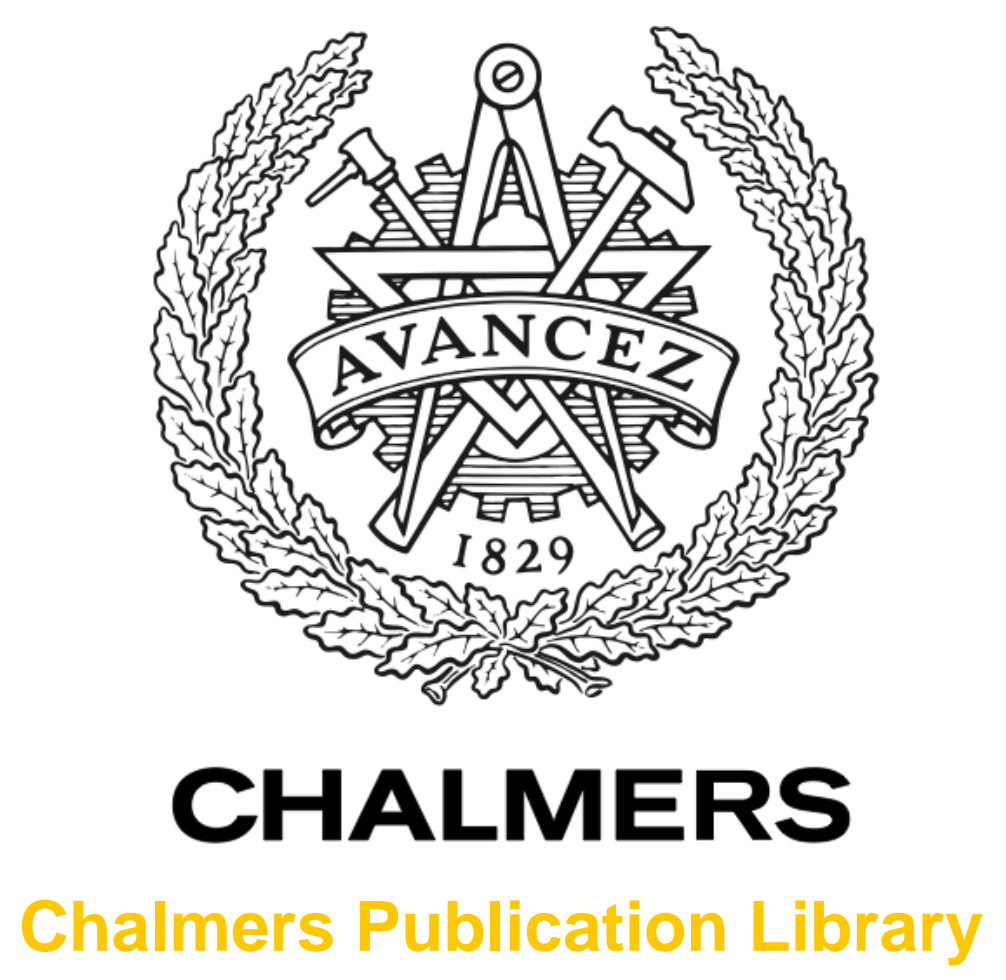

\title{
A minimum data set for evaluating the ecological soil functions in remediation projects
}

This document has been downloaded from Chalmers Publication Library (CPL). It is the author's version of a work that was accepted for publication in:

Journal of Soils and Sediments (ISSN: 1439-0108)

Citation for the published paper:

Volchko, Y. ; Norrman, J. ; Rosén, L. et al. (2014) "A minimum data set for evaluating the ecological soil functions in remediation projects". Journal of Soils and Sediments, vol.

14(11), pp. 1850-1860.

http://dx.doi.org/10.1007/s11368-014-0939-8

Downloaded from: http://publications.lib.chalmers.se/publication/201581

Notice: Changes introduced as a result of publishing processes such as copy-editing and formatting may not be reflected in this document. For a definitive version of this work, please refer to the published source. Please note that access to the published version might require a subscription.

Chalmers Publication Library (CPL) offers the possibility of retrieving research publications produced at Chalmers University of Technology. It covers all types of publications: articles, dissertations, licentiate theses, masters theses, conference papers, reports etc. Since 2006 it is the official tool for Chalmers official publication statistics. To ensure that Chalmers research results are disseminated as widely as possible, an Open Access Policy has been adopted.

The CPL service is administrated and maintained by Chalmers Library. 
Click here to download Manuscript: Volchko et al MDS J Soil Sed for review 20140507.docx Click here to view linked References

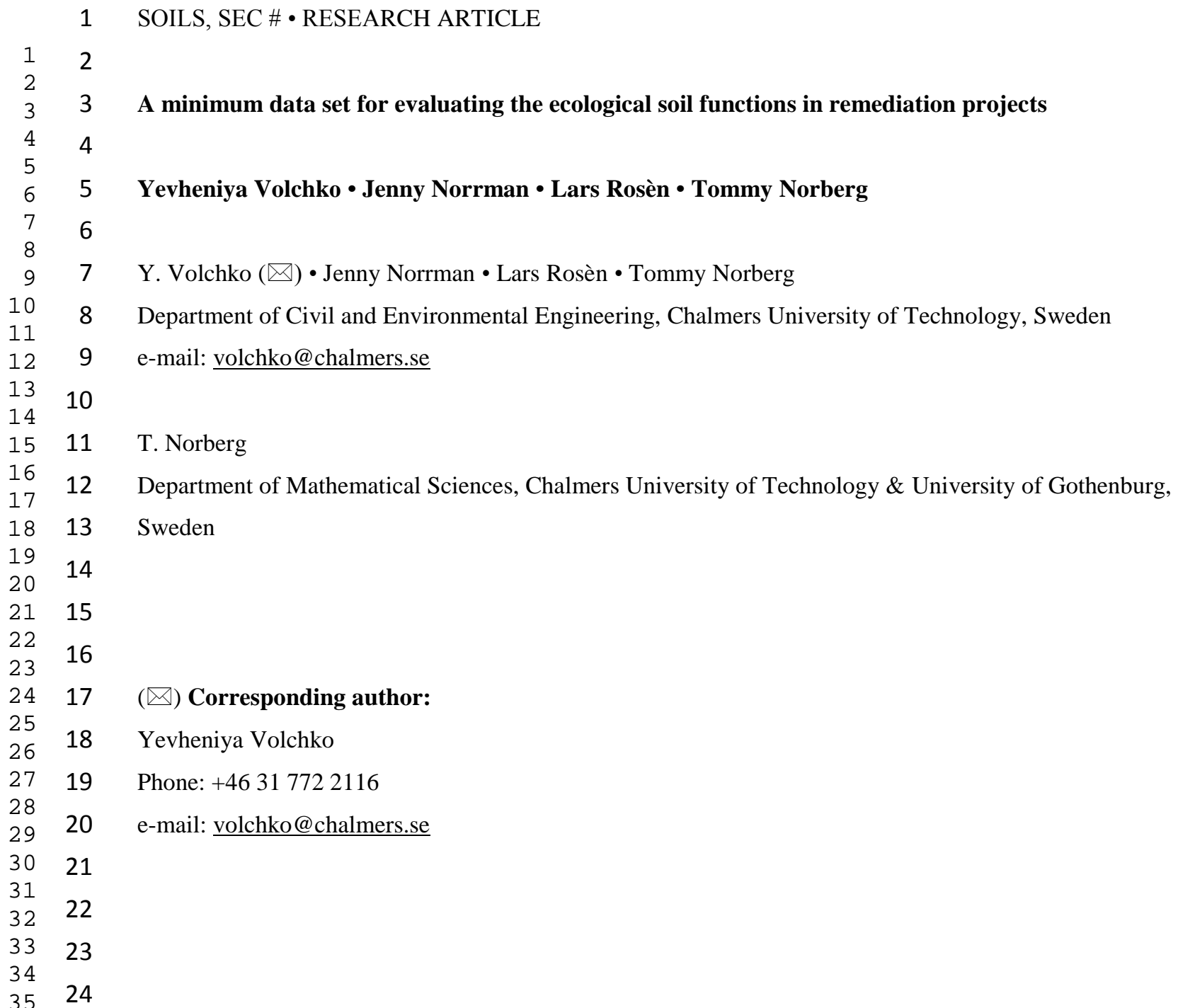

12 Department of Mathematical Sciences, Chalmers University of Technology \& University of Gothenburg, 13 Sweden 


\section{Abstract}

Purpose Soil functioning becomes a matter of growing concern in soil remediation projects as, apart from preparing contaminated land for construction purposes, some parts of the sites are usually transformed into green spaces for recreation and inspiration. The objective of this paper is to develop and apply a minimum data set (MDS) for evaluating the ecological soil functions for green areas in remediation projects.

Materials and methods The MDS was chosen from previous applications in literature. Using a nonlinear scoring algorithm to transform observed data into sub-scores for evaluating ecological soil functions, the MDS was applied on the Kvillebäcken site in Sweden. The mean sub-scores of the individual soil quality indicators (SQIs) were integrated into a soil quality index to classify the soil into one of five soil classes. Monte Carlo simulations were used to treat the uncertainties in the predicted soil class resulting from spatial heterogeneity of SQIs, a limited sampling size, and analytical errors.

Results and discussion The suggested MDS consists of soil texture, content of coarse material, available water capacity, organic matter content, potentially mineralizable nitrogen, pH, and available phosphorus. The high mean sub-score for organic matter at Kvillebäcken indicated that the soil was rich on organic matter thus having a good water storage, and nutrient cycling potential. However, the low mean sub-score for potentially mineralizable nitrogen indicated limited biological activity for nitrogen in the soil. The low mean sub-score for the content of coarse fragments indicated plant rooting limitations. Further, the soil quality index (that integrates the sub-scores for SQIs) corresponded to soil class 3 and a medium soil performance with a high certainty. Conclusions The suggested MDS can provide practitioners with relevant basic information on soil's ability to carry out its ecological functions. The suggested scoring method helps to interpret and integrate information from different SQIs into a decision-making process in remediation projects.

Keywords Contaminated sites/soil $\bullet$ Minimum data set $\bullet$ Remediation $\bullet$ Soil functions $\bullet$ Soil quality indicators 
Soil functions are critical for ecosystem survival and human well-being, because only a healthy soil can enable the entire ecosystem to function properly. Soil contamination is a widespread problem hindering a proper soil functioning in urban and rural environments. A remedial action is typically carried out to break up a pollutantreceptor linkage and reduce contaminant concentrations/amounts in the soil to the allowable levels guided by intended land use (Swedish EPA 2009). The guidance values are aimed at protecting human health and the environment. Specifically, for the soil environment the Swedish guideline values are aimed at protecting soil living organisms and the processes/functions they mediate (Swedish EPA 2009). Standardized tests exist to evaluate contaminated soils as well as to measure the success of the remedial action. However, these methods do not consider soil functions critical for ecosystems, e.g. basis for primary production, basis for biodiversity. While addressing a contamination problem, the remedial action itself may lead to such soil threats as erosion, compaction, loss of organic matter, decline in biodiversity, or acidification. To protect soils from the above mentioned threats, the proposed EU soil framework directive lists soil functions and services that should be accounted for in sustainable soil management practices. These include $(i)$ biomass production, including agriculture and forestry; (ii) storing, filtering and transforming nutrients, substances and water; (iii) biodiversity pool, such as habitats, species and genes; (iv) physical and cultural environment for humans and human activities; (v) source of raw materials; (vi) acting as carbon pool; (vii) archive of geological and archeological heritage (COM 2006).

To comply with the emerging regulatory requirements on soil protection, the decision making process on the best remediation alternative should include evaluation of soil functions within sustainability appraisal of available decision options. A decision option is usually a combination of land use and a remediation technology. Different end uses of the remediated site will result in different sets of desirable soil functions and services. Once land uses and a corresponding set of soil functions and services are identified, relevant soil quality indicators (SQIs) (i.e. physical, chemical and biological soil properties) can be used to evaluate the effects on soil functions and soil service indicators (SSIs) (i.e. value-related measurements) to evaluate the effects on soil services associated with possible remediation alternatives. Soil performance evaluation can be thus achieved on different spatial scales by using (1) SQIs that reflect effects on soil functions at the site level, and (2) SSIs that reflect effects on services resulting from the delivery of soil functions across all levels of the spatial scale (Volchko et al. 2013). A great many of today's soil scientists denote an equal degree of importance to three soil quality elements comprising of the physical, the chemical and the biological soil properties (e.g. Andrews et al. 2004; Doran and Zeiss 2000; Idowu et al. 2008; Karlen 2012; Schindelbeck et al. 2008). The chemical, physical and biological SQIs are usually examined to describe the soil's capacity to function and perform according to a specific purpose, e.g. tree plantation, gardening, grass field use. There is however no unified minimum data set (MDS) for soil function assessment, because each function of interest may demand different sets of SQIs sensitive to soil management (Lima et al. 2013). Indicator selection can be done using literature studies (e.g. Bone et al. 2010), expert opinion (e.g. Ritz et al. 2009), statistical procedures (e.g. Shchindelbeck et al. 2008), or combination of these to obtain reasonable MDS. Further, a challenging issue is that the same SQI can be interpreted differently for different soil functions (Lehmann and Stahr 2010). To overcome this difficulty, Idowu et al. (2008) suggest focusing on the soil processes that are related to crop production function. These soil processes are aeration, water infiltration, root penetration, energy/C storage, water and nutrient retention, ability 
of soil organisms to supply nitrogen, availability and leaching/environmental loss potential of phosphorus (Idowu et al. 2008). Still, interpretation of the test results would require professional judgment and placement into objectives of the soil end use (Schindelbeck et al. 2008). A nonlinear scoring algorithm is sometimes used to describe the relationship between a soil function and an SQI (e.g. Andrews et al. 2004; Gugino et al., 2009; Idowu et al. 2008; Karlen 2012; Lima, 2013; Schindelbeck et al. 2008). This relationship dictates the shape of a scoring curve that normalizes the measured SQI to a unit-less scale (e.g. fractional numbers between 0 and 1) enabling integration into a soil quality index.

\section{Aim and scope}

This study is aimed at providing an MDS that can facilitate integration of information on soil functions into the management decision process in remediation projects enabling practitioners to evaluate a change in soil functions as a result of remediation. The paper is organized as follows: Section 3 provides the reader with a candidate MDS for evaluating soil functions associated with primary production and cycling of water, carbon, nitrogen and phosphorus, Section 4 presents the methodology for soil function evaluation, Section 5 demonstrates an application of the MDS on a pilot case study and, finally, Section 6 discusses the proposed MDS and its applicability in decision support processes.

\section{Derivation of a candidate minimum data set}

The MDS should fulfill the following criteria: 1) sensitivity to variations in soil management; 2) good correlation with beneficial soil functions; 3) helpfulness in revealing ecosystem processes; 4) comprehensibility and utility for land managers; and 5) cheap and easy to measure (Doran and Zeiss 2000; Kruse 2007). Most commonly, MDSs have been developed for agronomic and vegetable production systems (e.g. Andrews et al. 2004; Larson and Pierce 1991; Reganold and Palmer 1995; Singer and Ewing 2000; Idowu et al. 2008). A critical review of SQIs and MDSs for agricultural purposes is provided in Kruse (2007). A review of the SQIs which are used for derivation of multi-parametric soil quality indices for agricultural soils are presented in Bastida et al. (2008). From these two reviews emerge that the most frequently used SQIs for agricultural purposes are organic matter, organic carbon, bulk density, aggregate stability, pH, electric conductivity (or salinity), forms of nitrogen, microbial biomass, and respiration.

There is a limited amount of studies aiming at providing MDSs for non-agricultural uses. Schindelbeck et al. (2008) suggests an MDS for soil health assessment that was applied for the soils of an urban vacant site and a grassfield in a rural park. Lehmann et al. (2008) and Lehmann and Stahr (2010) suggest using different sets of SQIs for specific soil end uses, e.g. soil as (i) basis for life and habitat of flora and fauna; (ii) site for grass land use or wheat production, (iii) filter and buffer of heavy metals. Further, based on a literature review, Bone et al. (2010) suggest an MDS of physical, chemical and biological SQIs for prioritizing contaminated urban sites for soil remediation. The study by Craul and Craul (2006) is aimed at providing an MDS and practical recommendations for successful planting of trees in the built environment. For contaminated sites, potential future land uses typically do not include crop production for agricultural purposes. However, apart from preparing contaminated land for construction purposes, some parts of the sites are usually transformed into green spaces for recreation and inspiration for which soil functions related to primary production are relevant. The MDSs that were suggested for non-agricultural use are arranged by literature sources and compiled in Table 1 . 
The SQIs used for evaluation of the effects on ecological soil functions in remediation projects are compiled in Table 2. The studies emphasize that the goal of remediation is not only to reduce contaminants concentrations/amounts in the soil, or reduce their bioavailability and mobility, but also to restore ecosystem functions. A concise description of the examined studies can be found in Volchko et al. (2013). The studies compiled in Table 2 combine conventional extraction tests and bioavailability tests with assessment of the effects on SQIs related to soil functioning. The study by Brown et al. (2005) uses bioavailability of contaminants in earthworms and small mammals as biological indicators of restored ecosystem functions. Epelde (2008a; 2009) studied the effects of phytoremediation on functional diversity of the soil microbial community. For evaluating the effects of bioremediation on ecosystem functions, Plaza et al. (2005) suggest using dragonflies and ostracods in bioavailability tests.

A candidate MDS for evaluation of the effects on ecological soil functions in remediation projects (Table 3) is identified by compiling SQIs that are (i) suggested by two or more literature sources in Table 1, (ii) suggested by three or more literature sources in Table 2 and consistent with the indicators in Table 1, (iii) relatively easy to measure and interpret.

\section{Methodology for soil function evaluation using MDS}

The effects on soil functions are here evaluated using the scoring method described by Andrews et al. (2004) and Schindelbeck et al. (2008). First, the sub-scores for content of coarse material (CM), available water capacity (AW), organic matter content $(\mathrm{OM})$, potentially mineralizable nitrogen $\left(\mathrm{NH}_{4}-\mathrm{N}\right), p H$, and available phosphorus (P) are computed using three types of scoring functions: "less is better", "more is better" and "optimum" (Fig. 1). These scoring functions transform input values of SQIs into fractional numbers between 0 and 1 , where the intervals [0;0.30], [0.31;0.7], [0.71;1] represent poor, medium and good soil qualities, respectively (for details see Volchko, 2013).. Using an approximation method (goodness-of-fit; Grapher ${ }^{\mathrm{TM}}$ software v.8), scoring functions for SQIs were determined based on data provided in the literature. The data reflecting the relationships between $\mathrm{AW}, \mathrm{OM}, \mathrm{NH}_{4}-\mathrm{N}, \mathrm{pH}$ and soil performances (sub-scores) were derived from Gugino et al. (2009). Based on recommendations in Craul and Craul (2006), the "less is better" scoring curve (described by Gaussian function) was developed for CM by scoring a coarse fraction content of less than $15 \%$ higher than 0.7 and more than $35 \%$ lower than 0.1. An "optimum" scoring curve (described by a system of equations) was developed for P based on agronomic optimum and environmentally critical values provided by Osztoics et al. (2011). For example, for coarse-textured soils a range of optimum values $(60-94 \mathrm{mg} \mathrm{AL}-\mathrm{P} / \mathrm{kg}$ ) is scored higher than 0.7 and environmentally critical value (188 AL-P/kg) is scored 0.1. Based on Gugino et al. (2009)and Osztoics et al. (2011), scoring curves for $\mathrm{AW}, \mathrm{OM}, \mathrm{NH}_{4}-\mathrm{N}$ and $\mathrm{P}$ were developed distinguishing fine-, medium- and coarsetextured soils (Fig. 1). Equations describing scoring curves can be found in Volchko (2013).

Thereafter, for integrating information from SQIs into the management decision process, all sub-scores are integrated into a soil quality index using the arithmetic mean of the sub-scores as suggested by Andrews et al. (2004).

165 The soil quality index forms a basis for soil classification into five soil classes corresponding to very good, good, medium, poor and very poor soil performances (Table 4).

Due to e.g. spatial heterogeneity of soil quality indicators, limited sampling sizes, and analytical errors the calculated mean values are associated with uncertainties. As a result, the predicted soil quality class is also 
subject to uncertainty. The uncertainties in the resulting soil quality index and the soil quality class were assessed by assigning probability distributions to the variables in the scoring model and running a Monte Carlo simulation with the Oracle ${ }^{\odot}$ Crystal Ball software. Monte Carlo simulation is a technique for calculating uncertainties in the model results by repeatedly picking values from the probability distributions for each uncertain variable in the model (Bedford and Cooke, 2001).

Translated and scaled $t$-distributions were used to represent the uncertainties of the mean value of each SQI. The parameters of the $t$-distribution are the mean value of the SQI, the scale $\left(\frac{s}{\sqrt{n}}\right)$, and the degrees of freedom $(n-1)$, where $s$ is the standard deviation and $n$ is the number of soil samples (Gelman et al. 2004).

\section{The Kvillebäcken case study}

The Kvillebäcken site is situated in Gothenburg, south-west Sweden. It is a former industrial site with small industries and other related activities. Eastern Kvillebäcken, which is a part of the redevelopment of a larger area (Fig. 2a), will primarily be developed as a residential area, with multi-family dwellings and elements such as retail premises, kindergartens, club rooms and the like. One part of the redevelopment area, in the vicinity of the residential area, is going to be turned into a green area. This area is located next to the Kvillebäcken stream (Fig. 2b). The west bank of the stream is a subject to remediation.

The superficial soil layers in the Kvillebäcken area consists of filling material with a variable thickness, over $2 \mathrm{~m}$ in Eastern Kvillebäcken and about $0.3-0.5 \mathrm{~m}$ in the western part. Beneath the filling material is glacio-marine clay with a thickness of about $30-40 \mathrm{~m}$, which is situated directly on rock, sometimes with a thin frictional layer in between the clay and the rock. Free-flowing groundwater appears in the lower part of the filling material, on top of the sealing clay, or in the fractured dry clay crust. The groundwater flow direction is considered east towards the Kvillebäcken stream. Locally, pipes and pipe trenches significantly affect the flow direction. Several environmental soil surveys have been carried out in the area. The studies show that soil is contaminated by past activities to a varying degree. High to very high concentrations of metals, aliphatic and aromatic hydrocarbons and PAHs have been detected in soil samples from the area. Groundwater sampling show that despite high levels of pollutants in the soil, generally no contaminants, metals or organic substances, is found in the groundwater. The effects of pollutants on soil layers from previous activities primarily concern the filling material, although the underlying clay in occasional points has also been superficially impacted in some locations.

Leaching tests for metals taken at the Kvillebäcken site have been performed on a collection of samples representing different filling materials. The concentrations at different ratios between liquid and solid material (L/S) were compared to the Swedish EPA's criteria for waste disposal. The concentrations of all investigated parameters are below the criteria for inert waste, with an exception for the fluoride content, which is slightly higher than the corresponding threshold (NCC Teknik 2000).

\subsection{Soil sampling and analysis methods for soil quality indicators}

The soil at the west bank of the stream within the future park area was sampled along a line parallel to the stream with an approximate sample separation of $25 \mathrm{~m}$ to a depth of $0.2 \mathrm{~m}$. Eight soil samples were collected in total. The soil samples for $\mathrm{pH}$, total $\mathrm{N}$ and available phosphorus were sieved through a $2 \mathrm{~mm}$ mesh at the laboratory before analysis. The particle size distribution analysis was performed by the soil sieving method, after the soil 
was oven-burned at $550^{\circ} \mathrm{C}$ (ISO 3310-2). The organic matter content was determined as a loss on ignition at $550^{\circ} \mathrm{C}$ (SS-EN 12879). Mineralizable $\mathrm{N}$ per week was determined using a first order exponential function (Stanford and Smith, 1972) and assuming that the soil $\mathrm{N}$ pool equals to $1-5 \%$ of total $\mathrm{N}$ (Springob and Kirchmann, 2003). Total $\mathrm{N}$ was measured by dry combustion in a Leco analyzer. $\mathrm{pH}$ was determined using a glass electrode in a 1:5 (volume fraction) suspension of soil in water (ISO 10390). Phosphorus was extracted with ammonium lactate and quantified by inductively coupled plasma (ICP) spectrometry (AL-P, Egner et al. 1960 and SS 02 8310). The available water capacity was indirectly determined by using the relationship between the FAO (Food and Agriculture Organization of the United Nations) soil texture class, organic matter content and bulk density as described by Lehmann et al. (2008).

\subsection{Soil function evaluation}

\section{Discussion and conclusions}

According to the FAO taxonomy triangle (Lehmann et al. 2008), the analyzed soil samples were silty loams except for two soil samples that were sandy loams and one soil sample that was silty clayey loam. Six out of eight soil samples had a coarse fragment ( $\varnothing>2 \mathrm{~mm}$ ) content higher than $35 \%$. The measured values for SQIs at the Kvillebäcken site are compiled in Table 5.

The analysis results of the eight soil samples were transformed into sub-scores. The transformation into subscores was done to: $(i)$ normalize input soil quality indicators, i.e. bringing the data from different scales (e.g. percentages and $\mathrm{mg} / \mathrm{kg}$ ) into one scale - fractional numbers in interval $[0 ; 1]$; and (ii) interpret the input data with respect to effects on ecological soil functions. Further, using the methodology for soil classification (Table 4), a mean soil quality index of 0.6 corresponding to soil class 3 and a medium soil performance was calculated for the entire area (Table 6).

Uncertainties associated with $\mathrm{NH}_{4}-\mathrm{N}$ were handled by assigning $t$-distribution to the total $\mathrm{N}$ values as specified in Section 4 and a beta distribution to the predicted percentage of mineralization to find a soil $\mathrm{N}$ pool (using minimum $=0$, maximum $=100 \%, 5$-th percentile $=1 \%$ and 95 -th percentile $=5 \%$ ). The Monte Carlo analysis was performed using 10000 runs, providing probabilities of the five possible soil quality classes. The simulation showed that with a probability of 0.75 , the simulated soil quality index corresponds to class 3 (medium soil performance) in the park area at Kvillebäcken (Fig. 3). For this specific case, the uncertainty in the soil class is very low; thus it is not motivated to sample the site further. However, for another case where the uncertainty is higher, further sampling to decrease the uncertainty may be relevant.

In order to know how a given SQI affects the soil quality index, sensitivity analysis was performed with Oracle ${ }^{\circledR}$ Crystal Ball. The sensitivity is calculated by computing correlation coefficients between each SQI and the resulting soil quality index. The sensitivity analysis results show that $\mathrm{pH}$ in the soil is the most sensitive input variable in the model and contributes most to the total uncertainty in the resulting soil quality index and thus the soil class (Fig. 4). For this specific case, the positive coefficient for $\mathrm{pH}$ indicates that the higher the value of this SQI the higher the soil quality index. In contrast, the negative coefficient for the gravel content indicates that the higher the value of the coarse fraction content the lower the resulting soil quality index.

\subsection{MDS}


This study presents a candidate MDS for evaluating ecological soil functions in remediation projects rather similar to SQIs frequently suggested for agricultural purposes. The suggested MDS consists of soil texture, content of coarse material, available water capacity, organic matter content, potentially mineralizable nitrogen, pH, and available phosphorus (Table 3). Soil texture was included in the MDS, because this inherent soil property (that does not change over relevant time horizons) can be impacted by a remedial action, e.g. when natural contaminated soil is substituted with a clean crushed rock material. Furthermore, it affects many of the important physical, biological, and chemical processes in a soil (Gugino et al. 2009). Cation exchange capacity (CEC) was omitted in the suggested MDS to avoid double-counting. Soil processes related to $C E C$ are covered by such SQIs as soil texture related to a capacity of the soil to bind contaminants, available phosphorus that is a measure of soil fertility, and organic matter content reflecting a nutrient cycling potential. For example, a sandy soil with low organic matter content would likely have a low $C E C$. If the low organic matter is addressed, the low $C E C$ will also be addressed. Potentially mineralizable nitrogen was included into the MDS as an indicator of a biological activity in the soil relevant for $\mathrm{N}$ cycling. However, this SQI alone can be misleading because if the soil microbial community has reached a steady state, a high activity for $\mathrm{N}$ can be caused by a $\mathrm{N}$-limited soil status. The $C / N$ ratio of the soil may inform on the magnitude of organic matter mineralization and immobilization. Respiration can be used as a complementary SQI for measuring microbial activity in the soil. However, it can be difficult to correctly interpret the analysis results (Nannipieri et al. 2003). A metabolic quotient $q \mathrm{CO}_{2}$ (respiration to microbial biomass ratio) can alternatively be used to inform on soil microbial activity. Further, some substitutions are possible for the selected SQIs. For example, organic matter content can be substituted with total organic carbon (TOC). The method used for TOC evaluation can also be combined with determination of total $C$ and $N$. Salinity can be an important SQI for some urban sites. Soils with high salt content would limit planting potential (Craul and Craul 2006). For the reason of the screening method used in this study, TOC, total $C$ and $N, C / N$ ratio, respiration, metabolic quotient and salinity are not a part of the suggested MDS, but may well be considered in further development of a MDS.

The screening method used for indicator selection in this study is quantitative (i.e. seeking for SQIs frequently used/suggested). The selected SQIs are based on traditional analysis methods. A more novel approach would be to look for newer possible indicators that traditionally have not been used very frequently but which may have a large potential. For example, the candidate biological indicators identified in an extensive screening study by Ritz et al. (2009) are (1) soil microbial taxa and community structure using terminal restriction fragment length polymorphism- (TRFLP-) based approaches; (2) soil microbial community structure and biomass from phospholipid fatty acids; (3) soil respiration and C cycling from multiple substrate-induced respiration; (4) biochemical processes from multi-enzyme profiling; (5) nematodes; (6) microarthropods; (7) on-site visual recording of soil fauna and flora; (8) pitfall traps for ground-dwelling and soil invertibrates. These indicators can assist in developing MDSs to assess soil functions associated with biodiversity, and habitat of flora and fauna. 282 Such profiling technique for the gene-based study as TRFLP has proven useful in the monitoring of a microbial 283 community during bioremediation (Hackl et al. 2012; Vázquez et al. 2009) and electrokinetic treatment of the contaminated soil (Pazos et al., 2012). By mapping the genetic structure it could be possible to determine/analyze whether the contaminated soil could be stimulated and recovered. Substrate-induced respiration and enzyme profiling have also been successfully used for monitoring the microbial diversity in the contaminated soil during phytoremediation (Epelde et al. 2008a; 2008b; 2009; 2010a; 2010b) and electrokinetic 
treatment (Pazos et al. 2012). To enable practical applicability of the above listed biological indicators, there is a need to establish standard operating procedures that would ensure reproducibility of results and resolve costeffectiveness issues (Ritz et al. 2009).

Soil depth becomes an important measurement for evaluating soil functions, because active life and habitat take place in the upper layers of the soil, i.e. down to 0.6-1 m below the surface. Recognizing that the physical soil structure strongly affects root penetration and growth, organic matter input, aeration, water infiltration and drainage (Schindelbeck 2008), it is recommended to maintain this SQI by building/preserving a well-structured soil profile. Such a profile consists of three basic layers: (1) the top layer of $15-20 \mathrm{~cm}$, which is rich on organic matter, (2) the sub-layer of 50-60 cm serving as mechanical support and as a reservoir of nutrients and water, and (3) the drainage layer of at least $15-20 \mathrm{~cm}$, which is capable of transmitting water excess from the sub-layer (Craul and Craul 2006). It should be mentioned that protection of the soil environment at large depths (deeper than $2-3 \mathrm{~m}$ ) is a common management practice for contaminated soils in Sweden. The upper $2 \mathrm{~m}$ are specified as having impact on the soil functions (Swedish EPA 2006). Soil fauna and flora can be found at the deeper depths but their importance for the ecosystem is limited (Swedish EPA 2006).

\subsection{Threshold values for SQIs}

The threshold values for soil quality indicators are dependent on the soil function of interest and the end use of the soil. For example, a threshold $p H$ value for a forest soil would be different from a threshold $p H$ value for a grass field soil. The threshold values for some SQIs changes with depth. For example, organic matter in the top layer is of great importance but less so in the subsoil, with typically a content of $<1 \%$ in natural subsoil (Craul and Craul 2006). The threshold values used in this study for scoring was developed by Gugino et al. (2009), Idowu et al. (2008), Shchindelbeck et al. (2008) emphasizing the importance of soil processes/functions related to crop production. It is assumed that the same threshold values are applicable to a grass field use of the studied remediation site.

\subsection{Applicability of the suggested MDS}

314 The suggested MDS was tested for a base case scenario (no remedial action is taken) using the Kvillebäcken site 315 in Sweden (Section 5). It was relatively inexpensive to analyse the suggested SQIs in a certified laboratory 316 (approximately $140 €$ per soil sample). However, the incubation method for determination of potentially 317 mineralizable nitrogen is not typically done in Sweden. Additional costs are therefore accrued by analysis of this 318 SQI. In this study, potentially mineralizable nitrogen was determined indirectly as a function of total $\mathrm{N}$ handling 319 the associated uncertainties with Monte Carlo simulations. Potentially mineralizable nitrogen can also be predicted as a function of the $\mathrm{NH}_{4}-\mathrm{N}$ concentration determined with a distillation method (Sharifi et al., 2007; Bushong et al, 2008). Thus, the $\mathrm{NH}_{4}-\mathrm{N}$ concentration may be used as a proxy of biological activity for $\mathrm{N}$ in the soil. The scoring approach suggested by Andrews et al. (2004), Gugino et al. (2009), Idowu et al. (2008) and Schindelbeck et.al (2008) allowed to apply the suggested MDS for soil function assessment. In order to apply other SQIs for soil functions assessment, relevant scoring functions should further be developed.

\subsection{Decision support}


Some remediation technologies can affect soil functions negatively, e.g. lead to erosion, compaction, loss of organic matter, decline in biodiversity, or acidification. Other technologies, e.g. immobilization of contaminants with amendments, can improve soil functions (enrich the soil with nutrients, improve soil structure and soil moisture retention, stimulate biological activity in the soil). To comply with the emerging regulatory requirements on soil protection and to assure a sustainable management of the soil environment, the decision making process on the best remediation alternative should include an evaluation of the effects on ecological soil functions. Since these effects should be evaluated against a reference remediation alternative, e.g. when no action is taken, it is important to examine the functional status of the soil in the base case scenario. The suggested MDS allows for soil assessment covering processes related to basis for primary production function, e.g. aeration, water infiltration, root penetration, energy/C storage, water and nutrient retention, ability of soil organisms to supply nitrogen, availability and leaching/environmental loss potential of phosphorus. Although the suggested MDS may be debatable (since some soil quality indicators are interrelated and there is no general consensus in the literature), it can provide practitioners in remediation projects with information on a soil's potential to function within future green areas of remediation site. The majority of the suggested MDS indicators is sensitive to variations in soil management, has good correlation with beneficial soil functions, and helps to reveal soil processes (Gugino et al. 2009). Aggregation of transformed SQIs into a soil quality index corresponding to a soil class may provide a manager of contaminated land with information on the capacity of the soil to perform its functions associated with primary production. This information can further be integrated into sustainability assessment of remediation alternatives using an approach suggested in Volchko et al. (2014). A soil function evaluation with the suggested MDS is here seen as being complementary to environmental risk assessment in remediation projects. Today standard risk assessment procedures are typically based on total content of contaminants. However, the risk is linked to the bioavailable fraction of the contaminants in the soil, and not only to total contaminant concentrations and amounts. Alternative remediation strategies such as application of amendments can both immobilize contaminants reducing their bioavailability in the soil (e.g. Siebielec and Chaney 2012) as well as enhance a functioning capacity of the soil (e.g. Alburquerque et al. 2011; Brown et al. 2005; van Herwijnen et al 2007). However, the use of such strategies is highly dependent on the use of bioavailability as a part of the risk assessment. Comprehensive soil assessment in remediation projects should integrate the improved risk assessment and soil function evaluation in order to assure sustainable management of contaminated soil.

Acknowledgements The authors thank two unanimous reviewers for the constructive comments that helped to improve the manuscript. The principal author thanks Professor Holger Kirchmann at Swedish University of Agricultural Sciences (SLU) for advice. The authors are grateful to the expert group at SLU for valuable discussions. The SNOWMAN Network, the Swedish EPA (Dnr 09/287) and the Swedish Research Council Formas (Dnr 242-2009-781) are gratefully acknowledged for financial support.

\section{References}

Alburquerque JA, de la Fuente C, Bernal MP (2011) Improvement of soil quality after "alperujo" compost application to two contaminated soils characterised by differing heavy metal solubility. J Environ Manage 92:733-741 
Andrews SS, Karlen DL, Cambardella CA (2004) The soil management assessment framework: a quantitative soil quality evaluation method. Soil Sci Soc Am J 68:1945-1962

Bastida F, Zsolnay A, Hernández T, García C (2008) Past, present and future of soil quality indices: A biological perspective. Geoderma 147:159-171

Bedford T, Cooke R (2001) Probabalistic Risk Analysis: Foundations and Methods. New-York, USA: Cambridge University Press

Bone J, Head M, Barraclough D, Archer M, Scheib C, Flight D, Voulvoulis N (2010) Soil quality assessment under emerging regulatory requirements. Environ Int 36:609-622

Brown S, Sprenger M, Maxemchuk A, Compton H (2005) Ecosystem Function in Alluvial Tailings after Biosolids and Lime Addition. J Environ Qual 34:139-148

Bushong JY, Roberts TL, Ross WJ, Norman RJ, Slaton NA, Wilson CE (2008) Evaluation of distillation and diffusion techniques for estimating hydrolysable amino sugar-nitrogen as a means of predicting nitrogen mineralization. Soil Science Society of America Journal 72: 992-999

COM (2006) Proposal for a Directive of the European Parliament and of the Council establishing a framework for the protection of soil and amending Directive 2004/35/EC. Brussels, Belgium

Craul TA and Craul PJ (2006) Soil Design Protocols for Landscape Architects and Contractors. Hoboken, New Jersey: John Wiley and Sons

Dawson JJC, Godsiffea EJ, Thompson IP, Ralebitso-Senior TK, Killhama KS, Paton GI (2007) Application of biological indicators to assess recovery of hydrocarbon impacted soils. Soil Biol Biochem 39:164-177

Doni S, Macci C, Peruzzi E, Arenella M, Ceccanti B, Masciandaro G (2012) In situ phytoremediation of a soil historically contaminated by metals, hydrocarbons and polychlorobiphenyls. J Environ Monit 14:13831390

Doran JW, Zeiss MR (2000) Soil health and sustainability: managing the biotic component of soil quality. Appl Soil Ecol 15:3-11

Egner H, Riehm H, Domingo WR (1960) Untersuchungen über die chemische Bodenanalyse als Grundlage für die Beurteilung desNahrstoffzustandes der Boden, II: Chemische Extractionsmetoden zu Phosphor und Kaliumbestimmung. Kunliga Lantbrukshügskolans Annaler 26:199-215

Epelde L, Becerril J M, Hernóndez-Allica J, Barrutia O, Garbisu C (2008 b) Functional diversity as indicator of the recovery of soil health derived from Thlaspi caerulescens growth and metal phytoextraction. Appl Soil Ecol 39(3):299-310

Epelde L, Becerril JM, Barrutia O, Gonza lez-Oreja JA, Garbisu C (2010b) Interactions between plant and rhizosphere microbial communities in a metalliferous soil. Environ Pollut 158:1576-83

Epelde L, Becerril JM, Kowalchuk GA, Deng Y, Zhiu J, Garbisu C (2010a) Impact of Metal Pollution and Thlaspi caerulescens Growth on Soil Microbial Communities. Appl Environ Microbiol 76(23):7843-7853

Epelde L, Becerril JM, Mijangos I, Garbisu C (2009) Evaluation of the efficiency of a phytostabilization process with biological indicators of soil health. J Environ Qual 38(5):2041-2049

Epelde L, Hernóndez-Allica J, Becerril JM, Blanco F, Garbisu C (2008 a) Effects of chelates on plants and soil microbial community: Comparison of EDTA and EDDS for lead phytoextraction. Sci Total Environ 401(13):21-28

Gelman A, Carlin JB, Stern HS, Rubin DB (2004) Bayesian Data Analysis. 2nd ed. Chapman \& Hall/CRC. 
GS (2008) Detaljplan för Östra Kvillebäcken södra delen. Utställningshandling. Stadsbyggnadskontoret. Göteborgs Stad

Gugino BK, Idowu OJ, Schindelbeck RR, van Es HM, Wolfe DW, Moebius-Clune BN, Thies JE, Abawi GS (2009) Cornell Soil Health Assessment Training Manual. 2nd ed. Ithaca: Cornell Digital Print Services

Hackl E, Schloter M, Szukics U, Bodrossy L, Sessitsch A (2012) From single Genes to microbial networks. In: Wall DH, Bardgett RD, Behan-Pelletier V, Herrick JE, Jones HT, Ritz K, Six J, Strong DR, van der Putten W.H. eds. Soil Ecology and Ecosystem Services. Oxford university press

Idowu OJ, van Es HM, Abawi GS, Wolfe DW, Ball JI, Gugino BK, Moebius BN, Schindelbeck RR, Bilgili AV (2008) Farmer-oriented assessment of soil quality using field, laboratory, and VNIR spectroscopy methods. Plant Soil 307:243-253

ISO 10381-6 (1993) Soil quality-Sampling. Guidance on the collection, handling and storage of soil for the assessment of aerobic microbial processes in the laboratory. International Organization for Standardization

ISO 10390 (2005) Soil quality - Determination of pH. International standard organization

ISO 3310-1 (2000) Test sieves - Technical requirements and testing -- Part 2: Test sieves of perforated metal plate. International Standard Organization

Jelusic M, Grcman H, Vodnik D, Suhadolc M, Lestan D (2013) Functioning of metal contaminated garden soil after remediation. Environ Pollut 174:63-70

Karlen DL (2012) Soil health: the concept, its role, and strategies for monitoring. In: Wall DH, Bardgett RD, Behan-Pelletier V, Herrick JE, Jones HT, Ritz K, Six J, Strong DR, van der Putten WH (eds) Soil Ecology and Ecosystem Services. Oxford university press

Kruse JS (2007) Framework for Sustainable soil Management: Literature Review and Synthesis. Soil and Water Conservation Society. Ankeny

Larson WE, Pierce FJ (1991) Conservation and enhancement of soil quality. In: Dumanski J, Pushparajah E, Latham M, Myers R eds. Evaluation for Sustainable Land Management in the Developing World. Vol. 2: Technical Papers. Proc. Int. Workshop., Chiang Rai, Thailand

Lear G, Harbottle MJ, Sills G, Knowles CJ, Semple KT, Thompson IP (2007) Impact of electrokinetic remediation on microbial communities within PCP contaminated soil. Environ Pollut 146(1):139-146

Lear G, Harbottle MJ, van der Gast CJ, Jackman SA, Knowles CJ, Sills G, Thompson IP (2004) The effect of electrokinetics on soil microbial communities. Soil Biol Biochem 36(11):1751-1760

Lehmann A, David S, Stahr K (2008) TUSEC-A manual for the evaluation of Natural Soils and AnthropogenicUrban Soils. Bilingual edition. Hohenheimer Bodenkundliche Hefte, Stuttgart

Lehmann A, Stahr K (2010) The potential of soil functions and planner-oriented soil evaluation to achieve sustainable land use. J Soils Sediments 10:1092-1102

Li H, Shi W-Y, Shao H-B, Shao M-A (2009) The remediation of the lead-polluted garden soil by natural zeolite. J Hazard Mater 169:1106-1111

Lima AC, Brussaard RL, Totola MR, Hoogmoed WB, de Goedeb RGM (2013) A functional evaluation of three indicator sets for assessing soil quality. Appl Soil Ecol 64:194-200 
Makino T, Kamiya T, Takano H, Itou T, Sekiya N, Sasaki K, Maejima Y, Sugahara K (2007) Remediation of cadmium-contaminated paddy soils by washing with calcium chloride: Verification of on-site washing. Environ Pollut 147(1):112-119

Nannipieri P, Ascher J, Ceccherini M T, Landi L, Pietramellara G, Renella G (2003) Microbial diversity and soil functions. Eur J Soil Sci 54:655-670

NCC Teknik (2000) Resultat-Översiktlig markmiljörundersökning inom Kvilleverkstaden 738:627. Geoteknik PM 03, NCC Teknik, Göteborg

Osztoics E, Sardi K, Csatho P, Radimszky L (2011) Characterization of soil P-supplying ability in terms of agronomy and environment protection. Agrokemia es talajtan 60: 175-190

Pazos M, Plaza A, Martin M, Lobo MC (2012) The impact of electrokinetic treatment on a loamy-sand soil properties. Chem Eng J 183:231-237

Plaza G, Nałęcz-Jawecki G, Ulfig K, Brigmon RL (2005) The application of bioassays as indicators of petroleum-contaminated soil remediation Chemosphere 59:289-296

Reganold JP, Palmer AS (1995) Significance of gravimetric versus volumetric measurements of soil quality under biodynamic, conventional, and continuous grass management. J Soil Water Conserv 50(3):298-305

Ritz K, Black HIJ, Campbell CD, Harris JA, Wood C (2009) Selecting biological indicators for monitoring soils: A framework for balancing scientific and technical opinion to assist policy development. Ecological Indicators 9: 1212-1221

Schindelbeck R, van Es HM, Abawi GS, Wolfe DW, Whitlow TL, Gugino BK, Idowu OJ, Moebius-Clune BN (2008) Comprehensive assessment of soil quality for landscape and urban management. Landscape Urban Plan 88:73-80

Sharifi M, Zebarth BJ, Burton DL, Grant CA, Bittman, S, Drury CF, McConkey BG, Ziadi N (2008) Response of potentially mineralizable soil nitrogen and indices of nitrogen availability to tillage system. Soil Science Society of America Journal 72, 1124-1131

Siebielec G, Chaney RL (2012) Testing amendments for remediation of military range contaminated soil. J Environ Manage 108:8-13

Singer MJ, Ewing SA (2000) Soil quality. In: Sumner, M. Handbook of soil sciences. USA: CRC Press

Springob G, Kirchmann H (2003) Bulk soil C to N ratio as a simple measure of net N mineralization from stabilized soil organic matter in sandy arable soils. Soil Biology and Biochemistry 36(4): 629-632

SS-EN 12879 (2000) Slam characterization - Loss on ignition. (In Swedish: Karaktärisering av slam Bestämning av torrsubstansförlust vid upphettning.) Swedish Standards Institute

Stanford G, Smith SJ. (1976) Estimating potentially mineralizable soil nitrogen from a chemical index of soil nitrogen availability. Soil Science 122: 71-76

Swedish EPA (2006) Improved environmental risk assessments. (In Swedish: Förbättrade miljöriskbedömningar.) Rapport 5538. Naturvårdsvärket

Swedish EPA (2009) Guideline values for contaminated land: Riktvärden för förorenad mark: Model description and a guide. (In Swedish: Modellbeskrivning och vägledning.) Rapport 5976. Naturvårdsvärket

van Herwijnen R, Al-Tabbaa A, Hutchings TR, Moffat A J, Ouki SK, Johns ML (2007) The Impact of Waste Compost-Based Soil Amendments on the Leaching Behavior of a Heavy Metal Contaminated Soil. Environ Eng Sci 24 (7):897-904 
Vázquez S, Nogales B, Ruberto L, Hernández E, Christie-Oleza J, Lo Balbo A, Bosch R Lalucat J, Mac Cormack W (2009) Bacterial community dynamics during bioremediation of diesel oil-contaminated Antarctic soil. Microb Ecol 57:598-610

Volchko Y (2013) SF Box - A tool for evaluating ecological soil functions in remediation projects. Report

ISSN

1652-9162.

Chalmers

Reproservice,

Gothenburg http://publications.lib.chalmers.se/records/fulltext/183250/183250.pdf

Volchko Y, Norrman J, Bergknut M, Rosén L, Söderqvist T (2013) Incorporating the Soil Function Concept into Sustainability Appraisal of Remediation Alternatives. J Environ Manage 129:367-376

Volchko Y, Norrman J, Rosén L, Bergknut M, Josefsson S, Söderqvist T, Norberg T, Wiberg K, Tysklind M (2014) Using soil function evaluation in multi criteria decision analysis for sustainability appraisal of remediation alternatives. Science of the Total Environment, special issue of AquaConSoil 2013, accepted for publication 23 January, 2014 

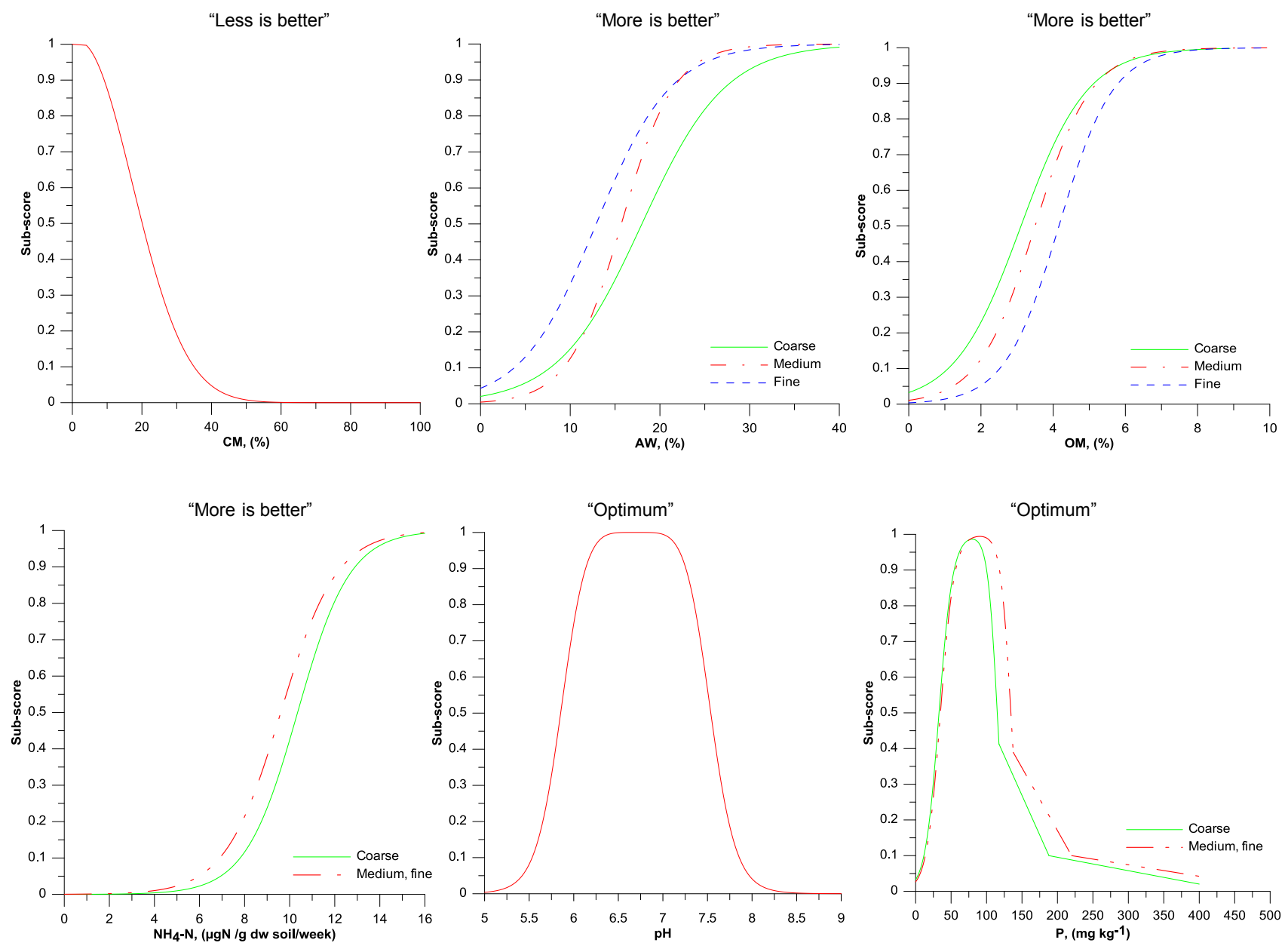
(a)

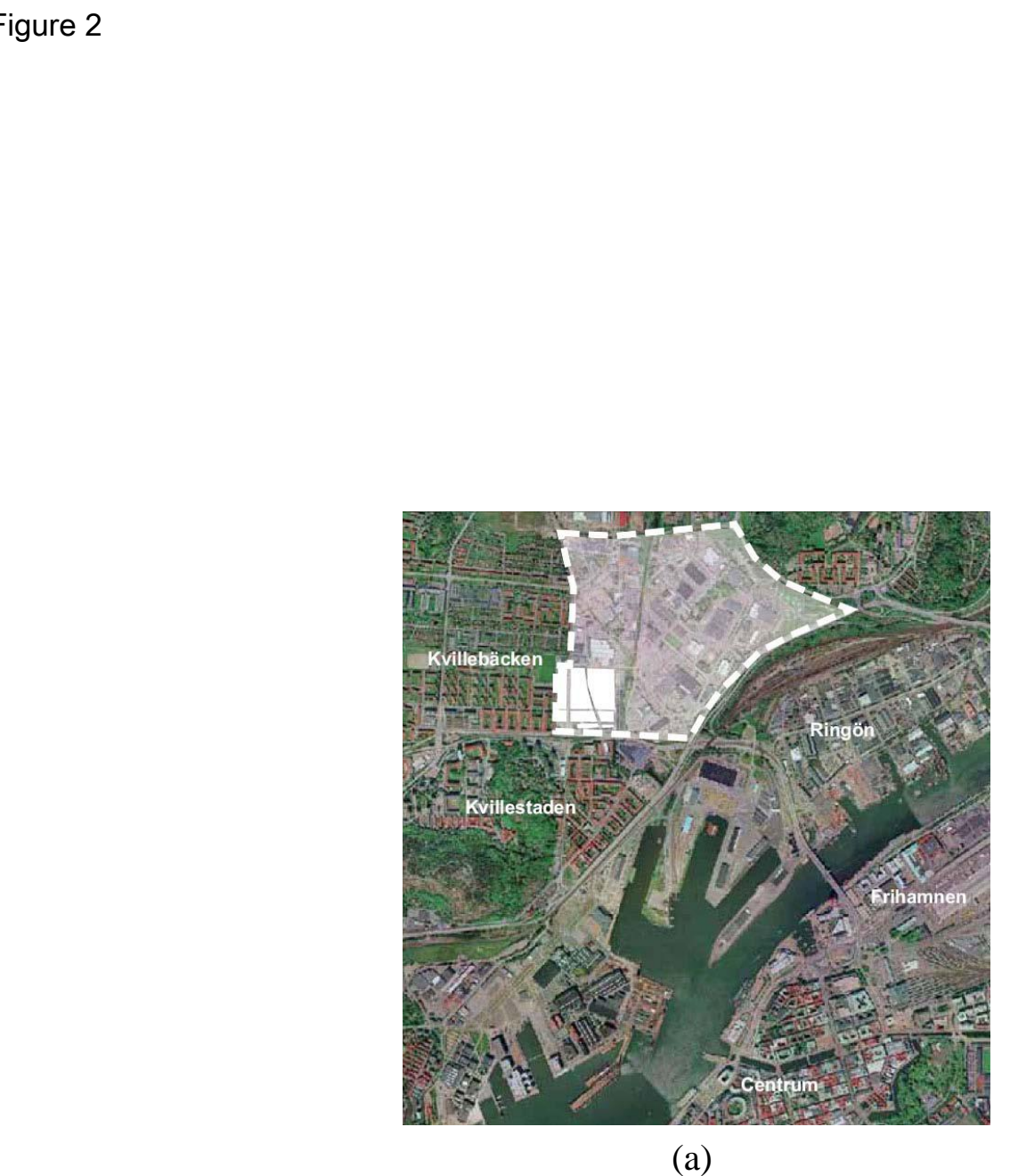

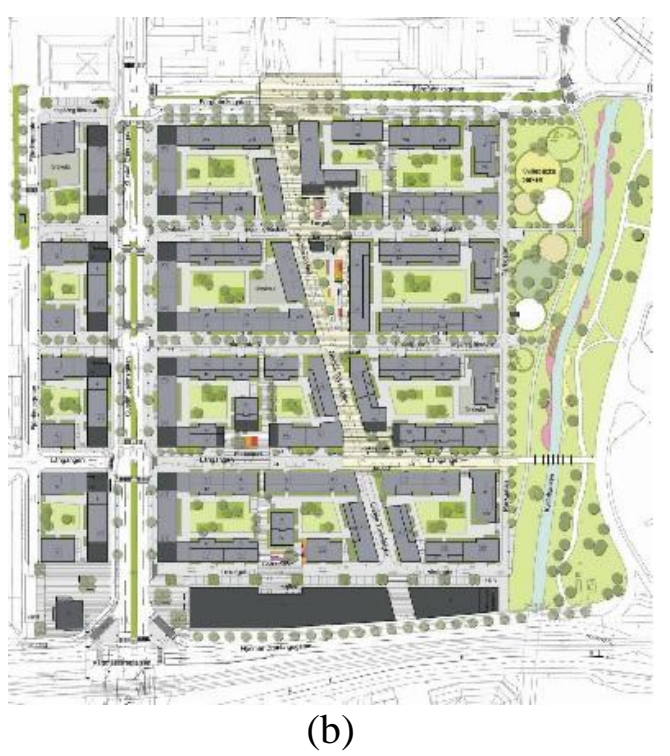

(b)

)

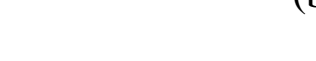

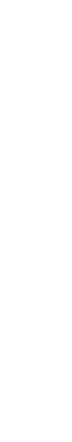

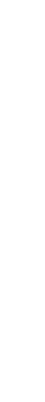

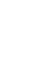

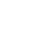

. 
Figure 3

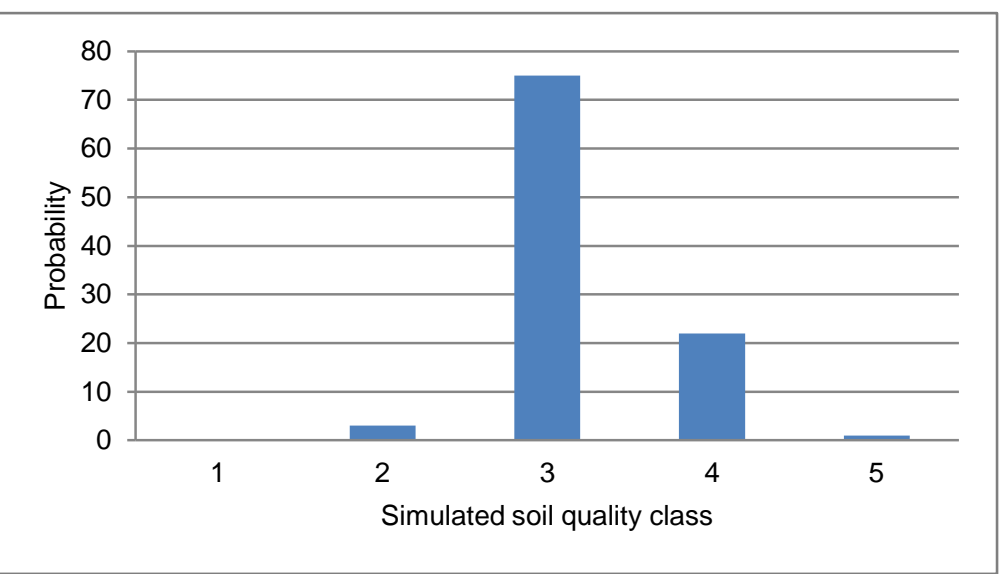


Figure 4

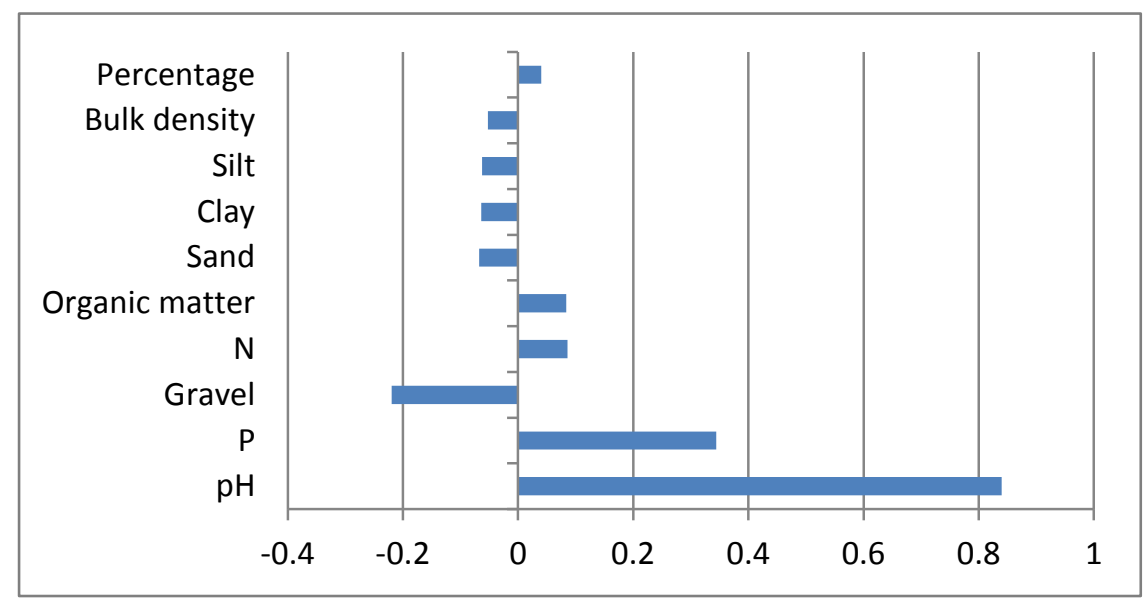


Table 1 MDSs for soil function evaluation suggested for non-agricultural use

\begin{tabular}{|c|c|c|c|}
\hline Schindelbeck et al. $(2008)^{1}$ & Bone et al. $(2010)^{2}$ & Craul and Craul $(2006)^{3}$ & Lehmann et al. $(2008)^{4}$ \\
\hline \multicolumn{4}{|l|}{ Physical Soil Quality Indicators } \\
\hline $\begin{array}{l}\text { - Soil texture } \\
\text { - Aggregate stability (\%) } \\
\text { - Available water capacity } \\
(\mathrm{m} / \mathrm{m}) \\
\text { - Surface hardness (psi) } \\
\text { - Subsurface hardness (psi) }\end{array}$ & $\begin{array}{l}\text { - Soil texture } \\
\text { - Infiltration rate } \\
\text { - Presence of } \\
\text { debris } \\
\text { - Soil odour } \\
\text { - Soil colour } \\
\text { - Penetrability }\end{array}$ & $\begin{array}{ll}\text { - } & \text { Soil texture } \\
\text { - } & \text { Soil moisture } \\
\text { - } & \text { Content of coarse } \\
\text { fragments }(\%) \\
\text { - } & \text { Structure of soil } \\
& \text { profile /Depth of soil } \\
& \text { layers } \\
\text { - } & \text { Slope of the surface }\end{array}$ & $\begin{array}{l}\text { - Soil texture } \\
\text { - Depth of horizon } \\
\text { - Available field capacity } \\
\left(1 / \mathrm{m}^{2}\right) \\
\text { - Content of coarse fragments } \\
\quad(\%) \\
\text { - Structure of soil profile } \\
\text { /Depth of soil layers } \\
\text { - Bulk density }\left(\mathrm{g} / \mathrm{cm}^{3}\right) \\
\text { - Soil colour } \\
\text { - Penetration potential/ } \\
\text { Rooting depth }(\mathrm{cm})\end{array}$ \\
\hline \multicolumn{4}{|c|}{ Biological Soil Quality Indicators } \\
\hline $\begin{array}{l}\text { - Organic matter }(\%) \\
\text { - } \text { Root health rating } \\
\text { - Active carbon (oxidizable } \\
\text { carbon) }(\mathrm{ppm}) \\
\text { - Potentially mineralizable } \\
\text { nitrogen }(\mu \mathrm{gN} / \mathrm{g} \mathrm{dw} / \text { week) }\end{array}$ & $\begin{array}{l}\text { - Organic carbon } \\
\text { - Root presence } \\
\text { - Plant cover } \\
\text { - Soil organism } \\
\text { presence and } \\
\text { diversity }\end{array}$ & - Organic matter $(\%)$ & - Organic matter $(\%)$ \\
\hline
\end{tabular}

Chemical Soil Quality Indicators

- $\mathrm{pH}$

- $\mathrm{pH}$

- $\mathrm{pH}$

- $\mathrm{pH}$

- Extractable P (ppm)

- Salinity (mS/cm)

- Cation exchange capacity

- Extractable K (ppm)

- $\mathrm{Ca}(\mathrm{ppm})$ $\mathrm{CEC}(\mathrm{mol} / \mathrm{kg})$

- Minor elements

${ }^{1}$ MDS for soil health evaluation (emphasis on processes related to crop production).

${ }^{2}$ MDS of "cross-functional" soil quality indicators for prioritizing contaminated urban sites.

${ }^{3}$ A list of soil quality indicators for successful planting of the trees in the urban areas.

${ }^{4}$ MDS for evaluation of the soil as basis for life and habitat of fauna and flora and for grassland use. 
Table 2 Soil quality indicators being used for evaluation of the impact of remediation on ecological soil functions

\begin{tabular}{|c|c|c|}
\hline \multicolumn{3}{|c|}{ Soil quality indicators } \\
\hline Physical & Chemical & Biological \\
\hline Soil structure $^{7}$ & $\mathrm{pH}\left(\mathrm{H}_{2} \mathrm{O}\right)^{1,2,3,4 \mathrm{a}, 4 \mathrm{~b}, 4 \mathrm{c}, 4 \mathrm{~d}, 4 \mathrm{e}, 5,6 \mathrm{a}, 6 \mathrm{~b}, 7,8,9,11}$ & Organic matter content ${ }^{1,4 a, 4 b, 4 c, 4 d, 4 e, 5,7,9}$ \\
\hline Soil texture ${ }^{1,4 a, 4 c, 4 d, 5,7,11}$ & $\mathrm{pH}\left(\mathrm{CaCl}_{2}\right)^{2,8}$ & Microbial biomass $C^{1,2,4 e, 6 a, 6 b}$ \\
\hline Water holding capacity ${ }^{1,4 a}$ & $\mathrm{pH}(\mathrm{KCl})^{8}$ & Microbial biomass $\mathrm{N}^{1}$ \\
\hline Water content ${ }^{4 \mathrm{~d}, 6 \mathrm{a}, 7}$ & Total CEC C $^{1,4 \mathrm{~b}, 4 \mathrm{c}, 5,7}$ & Microbial biomass/Soil DNA ${ }^{5}$ \\
\hline Temperature $^{6 a}$ & $\mathrm{CEC}(\mathrm{K}, \mathrm{Mg})^{1,8}$ & Respiration $2,6 \mathrm{a}, 6 \mathrm{~b}$ \\
\hline Porosity $^{9}$ & $\mathrm{CEC}(\mathrm{Ca})^{8}$ & Basal respiration/ C mineralization ${ }^{1,2,4 a, 4 d}$ \\
\hline Real density ${ }^{9}$ & Total $\mathrm{C}^{1,2,8}$ & Substrate-induced respiration ${ }^{1,4 \mathrm{a}, 4 \mathrm{~d}, 9}$ \\
\hline Electric conductivity ${ }^{4 b, 4 d, 6 a, 8,9}$ & $\mathrm{TOC}^{1,3}$ & Earthworm bioaccumulation $^{1}$ \\
\hline & Total $\mathrm{N}^{1,2,3,4 \mathrm{~b}, 4 \mathrm{c}, 4 \mathrm{~d}, 4 \mathrm{e}, 5,7,8,9,11}$ & Earthworm survival $^{1}$ \\
\hline & Nitrate $^{1,2,3,11}$ & Small mammals survival $^{1}$ \\
\hline & $\mathrm{C} / \mathrm{N}$ ratio $^{4 \mathrm{a}, 4 \mathrm{c}, 4 \mathrm{~d}, 4 \mathrm{e}}$ & Enzyme activity ${ }^{1,2,3,4 a, 4 b, 4 c, 4 d, 4 e, 9}$ \\
\hline & Total $\mathrm{P}^{3,11}$ & Potentially mineralizable nitrogen ${ }^{1,2,3,4 a, 4 c, 8,11}$ \\
\hline & Available $\mathrm{P}^{4 \mathrm{~b}, 4 \mathrm{c}, 4 \mathrm{~d}, 4 \mathrm{e}, 5,7,8,9,11}$ & Species richness ${ }^{4 a, 4 c}$ \\
\hline & Available $\mathrm{K}^{4 \mathrm{~b}, 4 \mathrm{c}, 4 \mathrm{e}, 5,7,9,11}$ & Shannon's diversity ${ }^{4 \mathrm{a}, 4 \mathrm{c}}$ \\
\hline & Available $\mathrm{Mg}^{4 \mathrm{~b}, 9,11}$ & Seed germination ${ }^{2,10}$ \\
\hline & Available $\mathrm{Ca}^{4 \mathrm{~b}, 9}$ & Root elongation $^{10}$ \\
\hline & Available $\mathrm{Na}^{9}$ & Dragonflies bioaccumulation ${ }^{10}$ \\
\hline & DTPA-Fe ${ }^{9}$ & Ostracods bioaccumulation ${ }^{10}$ \\
\hline & DTPA-Mn ${ }^{9}$ & \\
\hline & $\mathrm{CaCO}_{3}{ }^{9}$ & \\
\hline & Water soluble carbon ${ }^{3,4 \mathrm{e}}$ & \\
\hline & Total sulfate $^{11}$ & \\
\hline
\end{tabular}

${ }^{1}$ Brown et al. (2005): Immobilization of contaminants with biosolids. ${ }^{2}$ Dawson et al. (2007): Biopiling.

${ }^{3}$ Doni et al. (2012): Phytoremediation. $\quad{ }^{4 a}$ Epelde et al. (2008a): Phytoextraction. $\quad{ }^{4 b}$ Epelde et al..(2008b): Phytoextraction. ${ }^{4 c}$ Epelde et al. (2009): Phytoextraction. $\quad{ }^{4 d}$ Epelde et al. (2010a): Phytoextraction. ${ }^{4 e}$ Epelde et al.(2010b): Phytoextraction. ${ }^{5}$ Jelnsic et al. (2013): Soil washing with EDTA. ${ }^{6 a}$ Lear et al. (2004): Elektrokinetic treatment. ${ }^{6 \mathrm{~b}}$ Lear et al., (2007): Elektrokinetic treatment. ${ }^{7} \mathrm{Li}$ et al. (2009): Immobilization with zeolite. ${ }^{8}$ Makino et al. (2007): Soil washing. ${ }^{9}$ Pazos et al. (2012): Electrokinetic treatment.

${ }^{10}$ Plaza et al. (2005):Biopiling. ${ }^{11}$ van Herwijen et al. (2007): Immobilization of contaminants with compostbased soil amendments. 
Table 3 A candidate MDS for soil function evaluation in remediation projects

\begin{tabular}{|c|c|}
\hline Soil Quality Indicators & Relevance to Soil Functions \\
\hline Physical & Aggregate stability of the soil \\
\hline - $\mathrm{ST}$ & $\begin{array}{l}\text { Water infiltration, plant-available water and nutrient retention, aeration, root } \\
\text { penetration. }{ }^{1}\end{array}$ \\
\hline & $\begin{array}{l}\text { Buffering and filtering of heavy metals, the capacity of the soil to bind contaminants } \\
\text { and thus protect from contamination. }{ }^{2}\end{array}$ \\
\hline - $\mathrm{CM}$ & $\begin{array}{l}\text { The increased content of coarse particles }(>2 \mathrm{~mm} \text { ) and presence of debris affect soil } \\
\text { aggregate stability (i.e. ability to withstand falling apart when wet or hit by raindrops) }\end{array}$ \\
\hline & $\begin{array}{l}\text { as well as prevent plant rooting, decrease plant-available water and decline organic } \\
\text { matter levels. }{ }^{1}\end{array}$ \\
\hline - $\mathrm{AW}$ & $\begin{array}{l}\text { Water cycling. Water between the field capacity and the wilting point is the crucial } \\
\text { factor of storing water in the soil for soil organisms between precipitations. }{ }^{1}\end{array}$ \\
\hline Biological & Biodiversity and nutrient cycling \\
\hline - $\mathrm{OM}$ & $\begin{array}{l}\text { Carbon cycling. Presence of organic matter leads to (1) improvement of soil } \\
\text { aggregate stability, water storage potential, nutrient cycling, and (2) increased } \\
\text { microbial diversity/ activity and thus increased carbon sequestration. }{ }^{1}\end{array}$ \\
\hline - $\quad \mathrm{NH}_{4}-\mathrm{N}$ & $\begin{array}{l}\text { Nitrogen cycling. Ability of microbial communities to supply plant-available } \\
\text { nitrogen, a measure of biological activity. }{ }^{1}\end{array}$ \\
\hline Chemical & Nutrient retention and availability, buffering potential \\
\hline - $\mathrm{pH}$ & $\begin{array}{l}\text { The indicator revealing the level of toxicity and nutrient availability. }{ }^{1} \\
\text { Reflecting a potential for filtering and buffering of heavy metals. }{ }^{2}\end{array}$ \\
\hline - $\mathrm{P}$ & Phosphorus cycling. Macronutrient for plants and a measure of soil fertility. ${ }^{1}$ \\
\hline
\end{tabular}

${ }^{\mathrm{T}}$ Gugino et al. (2009), Idowu et al. (2008) and Schindelbeck et al. (2008).

${ }^{2}$ Lehmann et al. (2008).

ST: soil texture. CM: content of coarse material. AW: available water capacity. OM: organic matter content.

$\mathrm{NH}_{4}-\mathrm{N}$ : potentially mineralizable nitrogen. $\mathrm{P}$ : available phosphorus. 
Table 4 Correspondence between soil classes, soil performances and a soil quality index (modified after Gugino et al., 2009; Volchko et al. 2014)

\begin{tabular}{cll}
\hline Soil class & Soil performance & Soil quality index \\
\hline 1 & Very good & $>0.85$ \\
2 & Good & $0.70-0.85$ \\
3 & Medium & $0.55-0.69$ \\
4 & Poor & $0.40-0.54$ \\
5 & Very poor & $<0.40$ \\
\hline
\end{tabular}


Table 5 Statistics for the analyzed SQIs at the Kvillebäcken site

\begin{tabular}{lcccccc}
\hline & $\begin{array}{l}\mathrm{CM}, \\
{[\%]}\end{array}$ & $\begin{array}{c}\mathrm{AW}, \\
{[\%]}\end{array}$ & $\begin{array}{c}\mathrm{OM}, \\
{[\%]}\end{array}$ & $\begin{array}{c}\mathrm{NH}_{4}-\mathrm{N}, \\
{[\mu \mathrm{g} / \mathrm{g} \text { per } \mathrm{wk}]}\end{array}$ & $\mathrm{pH}$ & $\begin{array}{c}\mathrm{P}, \\
{[\mathrm{mg} / \mathrm{kg}]}\end{array}$ \\
\hline Mean & 39 & 25 & 8.1 & 6.4 & 5.8 & 59 \\
Std. & 12 & 5 & 4.3 & 4.1 & 0.6 & 38 \\
Min & 20 & 18 & 3 & 1.3 & 5 & 9 \\
Max & 55 & 31 & 16.8 & 15.2 & 6.5 & 134 \\
$\mathrm{CV}$ & 0.3 & 0.2 & 0.5 & 0.6 & 0.1 & 0.6 \\
\hline Std: standard deviation. & \multicolumn{7}{c}{ Max: maximum. } & Min: minimum. \\
CM: content of coarse material. AW: available water capacity. OM: organic matter content. \\
NH -N: potentially mineralizable N predicted as a function of total N. P: available phosphorus.
\end{tabular}


Table 6 Soil quality index as an arithmetic mean of the sub-scores for the measured SQIs

\begin{tabular}{|c|c|c|c|c|c|c|}
\hline & $\mathrm{CM}$ & AW & $\mathrm{OM}$ & $\mathrm{NH}_{4}-\mathrm{N}$ & $\mathrm{pH}$ & $\mathrm{P}$ \\
\hline Mean sub-score & 0.21 & 0.97 & 1 & 0.07 & 0.41 & 0.94 \\
\hline Soil quality & poor & good & good & poor & medium & good \\
\hline Mean soil quality index & 0.60 & & & & & \\
\hline Soil performance & medium & & & & & \\
\hline Soil class & 3 & & & & & \\
\hline
\end{tabular}

CM: content of coarse material. AW: available water capacity. OM: organic matter content.

$\mathrm{NH}_{4}-\mathrm{N}$ : potentially mineralizable nitrogen. $\mathrm{P}$ : available phosphorus. 